former by Drs. G. P. Clinton and F. A. McCormick of the Connecticut Agricultural Experiment Station at New Haven. Dr. Clinton and his associate report that the cause is a fungus, Fusicladium saliciperdum, and that it can be effectively controlled by repeated sprayings in the spring, four or five times from the period of bud swelling to the final expanding of the leaves, with Bordeaux mixture. They are continuing their investigations, the results of which are awaited with interest.

As a feature apparently not so far noticed is the fact that the White Poplar*(Populus alba) seems to be susceptible to the same disease. I saw repeated instances of it in various parts of the province. A similar disease was also noted on *Carolina poplar, but this appears to result from the attacks of an allied species of fungus.

Finally, a yellow spotting of Birch leaves (Betula populifolia) by $*$ Ex oascus flavus and a bark canker of the Aspen (Populus tremuloides) caused by ${ }^{*}$ Hypoxylon pruinatum constitute new records. The latter was first noted in some improvement thinnings where it was killing trees outright, but it was subsequently found several times elsewhere. It is important that acquaintance should be made with this disease of the Aspen and the Broad-toothed Poplar, and that care be taken to remove and burn affected trees from areas devoted to improvement operations. Hypoxylon canker is an insidious disease, easily overlooked, that works quickly and fatally in trees of all ages. Stands are known in which the mortality from this disease has been as great as seventy per centum.

\title{
REPORT ON SLASH DISPOSAL
}

At the Winnipeg meeting last year, I presented a summary dealing with the status of slash disposal in Canada, and I have been asked to review the progress during the year 1929 for the benefit of this Meeting. Accord ingly, I asked the several provincial forest authorities to provide me with a statement of slash disposal in their provinces, and am giving you the in formation received. Unfortunately, the response to my enquiries was not complete, so that the review I propose to make will not be entirely adequate.

Dealing with the provinces from east to west, I am advised by the Chief Forester of Nova Scotia that there has been no change in the policy in that province and that unfortunately no experiments in connection with slash disposal have been undertaken.

New Brunswick also reports no experimental work, but they have actually been successful in cleaning up a great deal of debris. Farmers' slash. ings are handled under fire permit, the actual work being supervised by a

* Not recorded before for Nova Scotia. 
forest officer, and the results have been very successful. The Service reports very little trouble, partly on account of prompt prosecution of violations and partly because the educational work involved in the supervision by the staff has borne fruit. A good deal of burning has taken place in connection with the clearing of transmission lines, the principal project being that of the St. John River Power Company. This work was in charge of the forest protection service of the International Paper Company, under general supervision of the Forest Service. Burning was carried on throughout the fre season, it being found that this could be safely done when portable gasoline fire pumps and other fire fighting equipment was available for proper control.

A great deal of work was also done in clearing up brush along the main provincial highway, resulting not only in an improvement in general appearance but also a great reduction in fire hazard. Real progress has been made in educating the road supervisors in the proper conduct of this work.

Slash adjacent to railway lines has been a matter of considerable trouble. According to the New Brunswick act, any slash created by operators within 300 feet must either be properly disposed of or hauled back beyond that limit. Some difficulty was encountered in inducing operators and their contractors to comply with the law, but co-operation and education is in this instance also getting results. Where selective cutting is being carried on, it is not always possible to burn the brush, and in such cases the tops are hauled back beyond the 300-foot limit and lopped.

With regard to woods operations, many of the lumber companies are now making it compulsory for their jobbers to clean up around camps. General slash disposal by burning is not required as yet because with the prevailing moist climate, slash, if properly lopped, rapidly decays. In addition, the close utilization by the pulpwood companies reduces the amount of debris remaining. In general, material is being taken to a three-inch top.

In the province of Quebec, lopping is also the prevailing requirement. $\mathrm{Mr}$. Piche advises that he is endeavouring to get the loggers to trim each tree right to the top. This not only provides proper lopping, but also facilitates close utilization. No slash burning experiments were conducted in Quebec during the year 1929.

I regret to state that so far as the provinice of Ontario is concerned, no answer was received to my enquiry. However, I have no doubt that $\mathrm{Mr}$. Zavitz will be able to supplement this statement with an explanation of what is being done in that province.

With regard to the areas under federal control, no further experiments have been carried on in either the Prairie Provincs or the Railway Belt of British Columbia. We have, however, adhered to our standard 
practice, which has been in effect now for more than a decade, namely, to require adequate brush disposal on all national forest timber operations. The method used naturally varies with the condition on the ground, although the standard requirement is live burning as the operation proceeds.

The province of British Columbia has carried out two slash disposal projects of a semi-experimental nature, and in this connection I would like to quote from Mr. Caverhill's letter:-

"Two years ago a 25-year timber sale was awarded in the Little White Mountain Provincial Forest near Okanagan Lake. The timber in the sale area consists of a mixture of spruce and balsam, with some scattered lodgepole pine. The contract requires all tops and slash to be piled and burned, together with all unmerchantable balsam, down to a D.B.H. of four inches, within 10 feet of each slash pile. All this work is to be done by the lessee at his expense. This kind of slash disposal is a new departure in our Interior spruce forests, and aims to cut down fre hazard from the slash, as well as to eliminate defective balsam and reduce the seed supply of this undesirable species. One year's cutting has been completed on this sale, with good observance of the slash disposal clauses. A careful study is being made of conditions on the cutover area, particularly with regard to the establishment of spruce regeneration.

"The second experiment consisted of the construction of three miles of fire lines in the railway tie timber sales in the lodgepole pine type of the Northern Interior. This was provided for in a clause in timbersale contracts which required the Lessee to spend one-half cent per tie on slash disposal, or do an equivalent amount of work. The slash disposal was done at the direction of the supervising forest officer and consisted of the construction of fire lines 20 to 30 feet wide, which are designed to assist in controlling the spread of fires. All trees and other growth on the lines are cut, piled, and burned and in the following spring a two-foot trench is plowed or grubbed to mineral soil."

Aside from this the British Columbia Service following its usual policy of broadcast burning areas of slash in the Douglas fir types. I might add that similar operations were carried on in the Coast district of the Railway Belt.

While the above information which I have retailed to you shows that some progress is being made along the lines of slash disposal, nevertheless, I think you will agree with me that the matter is not receiving that detailed attention which its importance merits. I do not think there is any person in this audience who will deny that the presence of slash in forest regions constitutes the greatest menace to our forests and is the reason in 90 per cent of all cases why forest fires get out of control. As the years go by, 
we all of us are becoming more and more convinced that the situation in Canada with regard to raw materials for our forest industries is becoming increasingly serious. We cannot afford to go on dissipating this resource through fire wastage to the extent which has been permitted in the past. Of the control measures which lie at our hand, that of proper slash dis. posal affords at the same time the most feasible and the most essential instrument for reduction of losses. It seems to me this Society should take a very strong stand on this matter and lend every effort to alleviate the present situation. Stricter governmental measures are not the only cure. In the long run the co-operation and assistance of the operators themselves must be secured. Many of you are connected with operating companies and can do your part in prosecuting a campaign for better slash disposal.

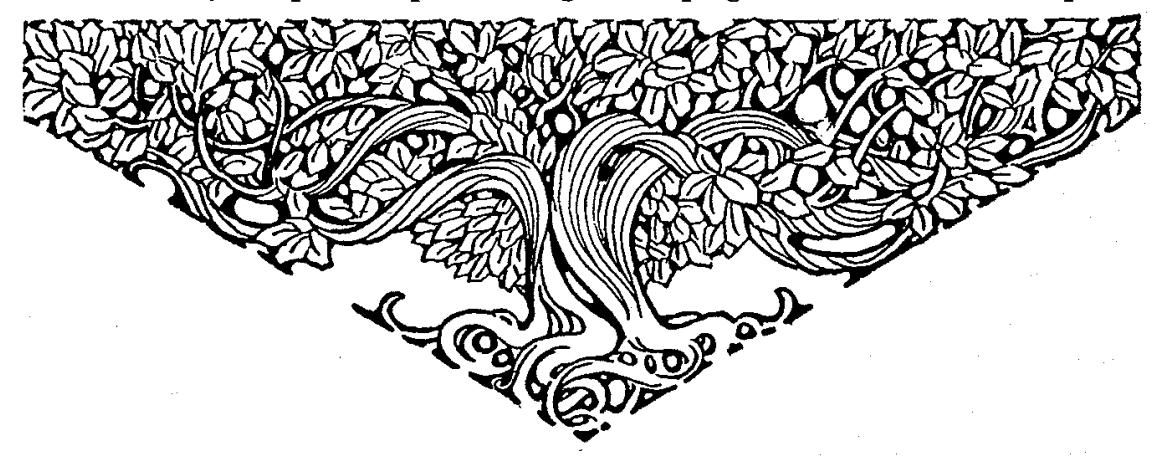

